\title{
SIX- AND SEVEN-COORDINATED MANGANESE(II) COMPLEXES OF QUATERPYRIDINE. SYNTHESIS, X-RAY CRYSTAL STRUCTURE AND CATALYST FOR ALKENE EPOXIDATION
}

\author{
CHIN-WING CHAN and CHI-MING CHE $†$ \\ Department of Chemistry, The University of Hong Kong, Pokfulam Road, Hong Kong \\ and

\section{SHIE-MING PENG} \\ Department of Chemistry, The National Taiwan University, Taiwan
}

(Received 23 March 1993; accepted 2 June 1993)

\begin{abstract}
Reaction of $\mathrm{Mn}\left(\mathrm{ClO}_{4}\right)_{2}{ }^{*} x \mathrm{H}_{2} \mathrm{O}$ and $\mathrm{Mn}\left(\mathrm{CH}_{3} \mathrm{CO}_{2}\right)_{3} \cdot x \mathrm{H}_{2} \mathrm{O}$ with $2,2^{\prime}: 6^{\prime}, 2^{\prime \prime}: 6^{\prime \prime}, 2^{\prime \prime \prime}$ quaterpyridine $(\mathrm{QP})$ in acetonitrile or methanol gave the complexes $\left[\mathrm{Mn}(\mathrm{QP})\left(\mathrm{H}_{2} \mathrm{O}\right)_{2}\right]$ $\left(\mathrm{ClO}_{4}\right)_{2}$ and $\left[\mathrm{Mn}(\mathrm{QP})\left(\mathrm{CH}_{3} \mathrm{CO}_{2}\right)\left(\mathrm{H}_{2} \mathrm{O}\right)\right]\left(\mathrm{ClO}_{4}\right)$, respectively. X-ray crystal structure determination revealed that the manganese atom is six-coordinated in the former, but sevencoordinated in the latter. Both complexes catalysed oxidation of alkenes by PhIO.
\end{abstract}

The coordination chemistry of polypyridine ligands is an active and important area of research. ${ }^{1.2}$ Despite the fact that $2,2^{\prime}$-bipyridine and $2,2^{\prime}: 6^{\prime}-2^{\prime \prime}$ terpyridine and their substituted derivatives have been subjected to extensive works, there are only a few studies on the ligand $2,2^{\prime}: 6^{\prime}, 2^{\prime \prime}: 6^{\prime \prime}, 2^{\prime \prime \prime}$-quaterpyridine (QP) ${ }^{3-5}$ This ligand is expected to be more oxidation resistant and has a low energy orbital for a metal-to-ligand charge transfer transition to occur in the visible region. As part of our program in the design of new oxidative and photochemical catalysts we explore the coordination chemistry of quaterpyridine with transition metal ions. Herein is described the synthesis and structural determination of six-and seven-coordinated manganese(II) complexes of QP. A preliminary study of catalytic epoxidation will be presented.

\section{EXPERIMENTAL}

\section{Materials}

$\mathrm{Mn}\left(\mathrm{CH}_{3} \mathrm{CO}_{2}\right)_{3} \cdot x \mathrm{H}_{2} \mathrm{O}$ and $\mathrm{Mn}\left(\mathrm{ClO}_{4}\right)_{2} \cdot x \mathrm{H}_{2} \mathrm{O}$ from Aldrich were used as received. The ligand $Q P$

$†$ Author to whom correspondence should be addressed. was prepared by literature methods. ${ }^{3}$ All solvents for syntheses and recrystallizations were of analytical grade.

\section{Physical measurements and instrumentation}

IR spectra were measured in $\mathrm{KBr}$ pellets on a Nicolet 20 SXC FT-IR spectrometer. UV-vis spectra were obtained on a Milton Roy Spectronic 3000 spectrophotometer.

Cyclic voltammograms were measured using a Princeton Applied Research (PAR) model 175 universal programmer, model 173 potentiostat and model 179 digital coulometer coupled to a Houston $2000 X-Y$ recorder. A conventional two-compartment cell was used in electrochemical measurements. A silver-silver nitrate (0.1 M in acetonitrile) reference electrode was used in degassed acetonitrile $\left[0.1 \mathrm{M}\right.$ in $\left.\left(\mathrm{CH}_{3}\left(\mathrm{CH}_{2}\right)_{3}\right)_{4} \mathrm{NPF}_{6}\right]$ with a ferroceniumferrocene $\left(\mathrm{Fc}^{+} / \mathrm{Fc}\right)$ couple as the internal standard. The working electrode was glassy carbon, which was pre-treated as described previously. ${ }^{6}$

$\left[\mathrm{Mn}(\mathrm{QP})\left(\mathrm{CH}_{3} \mathrm{CO}_{2}\right)\left(\mathrm{H}_{2} \mathrm{O}\right)\right]\left(\mathrm{ClO}_{4}\right)(1)$. A mixture of $\mathrm{Mn}\left(\mathrm{CH}_{3} \mathrm{CO}_{2}\right)_{3} \cdot x \mathrm{H}_{2} \mathrm{O}(0.2 \mathrm{~g})$ and $\mathrm{QP}(0.1 \mathrm{~g})$ in methanol $\left(30 \mathrm{~cm}^{3}\right)$ was heated at $50^{\circ} \mathrm{C}$ for $1 / 2 \mathrm{~h}$, after which the mixture was filtered. The filtrate was 
treated with $\mathrm{LiClO}_{4}$ to give a pale yellow solid, which was then filtered and air dried.

$\left[\mathrm{Mn}(\mathrm{QP})\left(\mathrm{H}_{2} \mathrm{O}\right)_{2}\right]\left(\mathrm{ClO}_{4}\right)_{2}$ (2). Excess $\mathrm{Mn}\left(\mathrm{ClO}_{4}\right)_{2}$. $x \mathrm{H}_{2} \mathrm{O}$ and $\mathrm{QP}$ were mixed in acetonitrile $(50$ $\mathrm{cm}^{3}$ ) at $70^{\circ} \mathrm{C}$. The resulting solution was stirred for $15 \mathrm{~min}$, filtered and concentrated to $c a 10$ $\mathrm{cm}^{3}$. Ether diffusion afforded greenish-yellow ncedles. IR $\left(\mathrm{cm}^{-1}\right): 1597 \mathrm{~m}, 1575 \mathrm{~m}, 1490 \mathrm{~m}, 1466 \mathrm{~m}$, $1440 \mathrm{~m}, 1314 \mathrm{w}, 1249 \mathrm{w}, 1192 \mathrm{w}, 1110 \mathrm{~s}, 1088 \mathrm{~s}, 1016 \mathrm{w}$, $777 \mathrm{~s}, 652 \mathrm{w}, 625 \mathrm{~m}, 429 \mathrm{w}$. UV-vis in $\mathrm{CH}_{3} \mathrm{CN}\left(\lambda_{\max }\right.$, $\left.10^{-3} \varepsilon\right):(235,35.2),(294,18.1),(301,26.1),(332$, $16.2),(342,16.9)$.

\section{$X$-ray crystallography}

Yellow crystals of $\left[\mathrm{Mn}(\mathrm{QP})\left(\mathrm{CH}_{3} \mathrm{CO}_{2}\right)\left(\mathrm{H}_{2} \mathrm{O}\right)\right]$ $\left(\mathrm{ClO}_{4}\right)(\mathrm{I})$ and $\left[\mathrm{Mn}(\mathrm{QP})\left(\mathrm{H}_{2} \mathrm{O}\right)_{2}\right]\left(\mathrm{ClO}_{4}\right)_{2}$ (2) were obtained by diffusion of diethyl ether into the corresponding acetonitrile solution. The intensity data were measured on an Enraf--Nonius CAD4 diffractometer equipped with graphite monochromatized $\mathrm{Mo}-K_{\alpha}$ radiation $(\lambda=0.7093$ A) using a $\theta-2 \theta$ scan mode at $297 \mathrm{~K}$ with $2 \theta_{\max }=50^{\circ}$. Cell parameters and the space group were obtained from 24 strong reflections with 20 in the ranges $18-27^{\circ}$ and $19-25^{\circ}$ for complexes 1 and 2 , respectively. For complex 1 a total of 8678 reflections were measured, 8295 of which were considered unique and 5486 of these had $I>2 \sigma(I)$; while for complex 2 a total of 2233 reflections were collected, in which 592 reflections with $I>2 \sigma(I)$ were con- sidered out of 2142 unique reflections. All data were corrected for Lorentz and polarization effects. Empirical absorption corrections were applied. In the final cycle of refinement convergence was reached at $R=0.045, R_{\mathrm{w}}=0.033, S=2.56$ for complex 1 and $R=0.070, R_{\mathrm{w}}=0.070, S=1.99$ for complex 2. Final difference densities were in the range $-0.62-0.86$ e $\AA^{-3}$ for complex 1 and $-0.56-0.70$ e $\AA^{-3}$ for complex 2. A summary of crystallographic data is listed in Table 1. Selected bond lengths and bond angles are listed in Table 2 .

\section{Alkene oxidation by iodosobenzene catalysed by complex 2}

The reaction was conducted in degassed $\mathrm{CH}_{2} \mathrm{Cl}_{2} / \mathrm{CH}_{3} \mathrm{CN}$ solution (3:1 volume) and under nitrogen. A mixture of complex $2(7 \mathrm{mg})$, alkene ( 40 $\mathrm{mg}$ ) and $\mathrm{PhIO}(30 \mathrm{mg})$ was stirred for 3-6 h. Excess sodium sulphite $(100 \mathrm{mg}$ ) was added in water (3 $\left.\mathrm{cm}^{3}\right)$. After excess PhIO was decomposed the organic layer was separated. The aqueous layer was extracted with $3 \times 2 \mathrm{~cm}^{3}$ of $\mathrm{CH}_{2} \mathrm{Cl}_{2}$. The combined organic layer was evaporated to dryness under reduced pressure. 3-Methylbenzoic acid ( $3 \mathrm{mg}$ ) was added as an internal standard. The mixture was extracted with $3 \times 5 \mathrm{~cm}^{3}$ petroleum ether $\left(40-60^{\circ} \mathrm{C}\right)$, filtered through a cotton plug and evaporated under reduced pressure. NMR spectra were taken on the residues obtained.

Table 1. Crystallographic data for $\left[\mathrm{Mn}(\mathrm{QP})\left(\mathrm{H}_{2} \mathrm{O}\right)_{2}\right]\left(\mathrm{ClO}_{4}\right)_{2}$ and $\left[\mathrm{Mn}(\mathrm{QP})\left(\mathrm{H}_{2} \mathrm{O}\right)\left(\mathrm{CH}_{3} \mathrm{CO}_{2}\right)\right]\left(\mathrm{ClO}_{4}\right)\left(\mathrm{H}_{2} \mathrm{O}\right)$

\begin{tabular}{|c|c|c|}
\hline Compound & $\mathrm{MnC}_{20} \mathrm{H}_{18} \mathrm{~N}_{4} \mathrm{Cl}_{2} \mathrm{O}_{10}$ & $\mathrm{MnC}_{22} \mathrm{H}_{2 !} \mathrm{N}_{4} \mathrm{ClO}_{8}$ \\
\hline Mol, wt & 600.22 & 559.83 \\
\hline Crystal system & Monoclinic & Triclinic \\
\hline Space group & $C 2 / c$ & $P \mathrm{I}$ \\
\hline$a(\AA)$ & $14.299(2)$ & $13.619(2)$ \\
\hline$b(\AA)$ & $11.164(3)$ & $13.848(2)$ \\
\hline$c(\AA)$ & $15.422(5)$ & $13.865(3)$ \\
\hline$\alpha\left(^{\circ}\right)$ & 90 & $81.26(2)$ \\
\hline$\left.\beta 0^{\circ}\right)$ & $99.94(2)$ & $111.94(1)$ \\
\hline$\gamma\left({ }^{\circ}\right)$ & 90 & $102.82(1)$ \\
\hline$V\left(\AA^{3}\right)$ & $2424.9(1)$ & $2358.0(7)$ \\
\hline$F(000)$ & 1220 & 1148 \\
\hline$Z$ & 4 & 4 \\
\hline$D_{\text {cakc }}\left(\mathrm{g} \mathrm{cm}^{-3}\right)$ & 1.644 & 1.580 \\
\hline$R$ & 0.070 & 0.045 \\
\hline$R_{\mathrm{w}}$ & 0.070 & 0.033 \\
\hline$\rho\left(\mathrm{e} \AA^{-3}\right)$ & $-0.56,+0.70$ & $-0.62,+0.86$ \\
\hline$\mu\left(\mathrm{mm}^{-1}\right)$ & 0.80 & 0.70 \\
\hline
\end{tabular}


Table 2. Selected bond lengths $(\AA)$ and bond angles $\left(^{\circ}\right)$ for $\left[\mathrm{Mn}(\mathrm{QP})\left(\mathrm{H}_{2} \mathrm{O}\right)\left(\mathrm{CH}_{3} \mathrm{CO}_{2}\right)\right]\left(\mathrm{ClO}_{4}\right)(\mathbf{1})$ and $[\mathrm{Mn}(\mathrm{QP})$ $\left.\left(\mathrm{H}_{2} \mathrm{O}\right)_{2}\right]\left(\mathrm{ClO}_{4}\right)_{2}(2)$

\begin{tabular}{lllll}
\hline & 1 & $1^{a}$ & & 2 \\
\hline $\mathrm{Mn}-\mathrm{O}(5)$ & $2.164(3)$ & $2.193(3)$ & $\mathrm{Mn}-\mathrm{O}($ water $)$ & $2.179(5)$ \\
$\mathrm{Mn}-\mathrm{O}(1), \mathrm{O}(2)$ & $2.323(3), 2.301(3)$ & $2.271(3), 2.300(3)$ & - & - \\
$\mathrm{Mn}-\mathrm{N}(1), \mathrm{N}(4)$ & $2.360(3), 2.367(3)$ & $2.337(3), 2.347(3)$ & $\mathrm{Mn}-\mathrm{N}(1), \mathrm{N}(1 \mathrm{~A})$ & $2.282(5)$ \\
$\mathrm{Mn}-\mathrm{N}(2), \mathrm{N}(3)$ & $2.318(3), 2.311(3)$ & $2.291(3), 2.289(3)$ & $\mathrm{Mn}-\mathrm{N}(2), \mathrm{N}(2 \mathrm{~A})$ & $2.214(6)$ \\
$\mathrm{C}(15)-\mathrm{C}(16)$ & $1.48(1)$ & $1.48(1)$ & $\mathrm{C}(5)-\mathrm{C}(6)$ & $1.46(1)$ \\
$\mathrm{C}(20)-\mathrm{C}(21)$ & $1.49(1)$ & $1.49(1)$ & $\mathrm{C}(10)-\mathrm{C}(10 \mathrm{~A})$ & $1.48(1)$ \\
$\mathrm{N}(1)-\mathrm{Mn}-\mathrm{N}(4)$ & $151.6(1)$ & $149.6(1)$ & $\mathrm{N}(1)-\mathrm{Mn}-\mathrm{N}(1 \mathrm{~A})$ & $144.5(2)$ \\
$\mathrm{N}(1)-\mathrm{Mn}-\mathrm{N}(2)$ & $68.5(1)$ & $69.2(1)$ & $\mathrm{N}(1)-\mathrm{Mn}-\mathrm{N}(2)$ & $72.0(2)$ \\
$\mathrm{N}(2)-\mathrm{Mn}-\mathrm{N}(3)$ & $69.3(1)$ & $69.8(1)$ & $\mathrm{N}(2)-\mathrm{Mn}-\mathrm{N}(2 \mathrm{~A})$ & $71.4(2)$ \\
$\mathrm{N}(1),(4)-\mathrm{Mn}-\mathrm{O}(5)$ & $82.4(1), 80.3(1)$ & $81.0(1), 80.9(1)$ & $\mathrm{N}(1)-\mathrm{Mn}-\mathrm{O}(1)$ & $84.3(2)$ \\
$\mathrm{N}(1),(4)-\mathrm{Mn}-\mathrm{O}(1)$ & $99.6(1), 87.7(1)$ & $95.1(1), 94.7(1)$ & & $86.6(2)$ \\
$\mathrm{N}(1)-\mathrm{Mn}-\mathrm{O}(2)$ & $80.6(1)$ & $79.9(1)$ & - & - \\
$\mathrm{N}(2),(3)-\mathrm{Mn}-\mathrm{O}(5)$ & $106.7(1), 103.2(1)$ & $102.4(1), 100.4(1)$ & $\mathrm{N}(2)-\mathrm{Mn}-\mathrm{O}(1)$ & $101.6(2)$ \\
$\mathrm{N}(2),(3)-\mathrm{Mn}-\mathrm{O}(1)$ & $95.9(1), 91.5(1)$ & $92.2(1), 94.1(1)$ & & $102.7(2)$ \\
$\mathrm{N}(4)-\mathrm{Mn}-\mathrm{O}(2)$ & $80.7(1)$ & $81.5(1)$ & - & - \\
$\mathrm{O}(5)-\mathrm{Mn}-\mathrm{O}(1)$ & $156.2(1)$ & $162.2(1)$ & $\mathrm{O}(1)-\mathrm{Mn}-\mathrm{O}(1 \mathrm{~A})$ & $150.0(2)$ \\
$\mathrm{O}(5)-\mathrm{Mn}-\mathrm{O}(2)$ & $100.9(1)$ & $105.0(1)$ & - & - \\
$\mathrm{N}(1)-\mathrm{C}(15)-\mathrm{C}(16)$ & $115.6(3)$ & $114.9(3)$ & $\mathrm{N}(1)-\mathrm{C}(5)-\mathrm{C}(6)$ & $116.4(6)$ \\
$\mathrm{N}(2)-\mathrm{C}(20)-\mathrm{C}(21)$ & $115.2(4)$ & $115.4(4)$ & & $114.3(6)$ \\
\hline
\end{tabular}

${ }^{a}$ There are two independent manganese complexes in an asymmetric unit of $\mathbf{1 .}$

\section{RESULTS AND DISCUSSION}

\section{$X$-ray structure determination}

The reaction of quaterpyridine with $\mathrm{Mn}\left(\mathrm{CH}_{3}\right.$ $\left.\mathrm{CO}_{2}\right)_{3} \cdot x \mathrm{H}_{2} \mathrm{O}$ in methanol or ethanol rapidly gave $\left[\mathrm{Mn}(\mathrm{QP})\left(\mathrm{CH}_{3} \mathrm{CO}_{2}\right)\left(\mathrm{H}_{2} \mathrm{O}\right)\right]^{+}$, which was isolated as the perchlorate salt in high yield. A similar reaction with $\mathrm{Mn}\left(\mathrm{ClO}_{4}\right)_{2}$ in acetonitrile gave the six-coordinated $\left[\mathrm{Mn}(\mathrm{QP})\left(\mathrm{H}_{2} \mathrm{O}\right)_{2}\right]\left(\mathrm{ClO}_{4}\right)_{2}$. The IR spectrum of 1 shows strong absorption bands at 3400 and $3230 \mathrm{~cm}^{-1}$, attributed to $v\left(\mathrm{OH}_{2}\right)$ stretches. The UV-vis absorption spectrum of 1 or 2 in acetonitrile is featureless, being dominated by the intraligand $\pi \rightarrow \pi^{*}$ transitions at 342,333 and $302 \mathrm{~nm}$.

The structures of the manganese complexes 1 and 2 have been determined by X-ray crystallography. There are two independent molecules of complex 1 in an asymmetric unit, but these are not significantly different from each other (see Table 2). A perspective view of one cation of 1 with its atomic numbering scheme is shown in Fig. 1. The central manganese atom adopts the common coordination geometry for seven-coordinated manganese(II) complexes-distorted pentagonal-bipyramidal. ${ }^{7}$ The equatorial sites are occupied by the four nitrogen atoms of quatcrpyridine and one of two oxygen atoms of the chelating acetate ligand. The $\mathrm{N}_{4} \mathrm{O}$ donor set of atoms, which form the pentagon, are approximately co-planar with the acetate oxygen atom slightly deviating from the plane defined by $\mathrm{N}(1)-\mathrm{N}(4)$. The measured $\angle \mathrm{O}(1)$ acetate $\mathrm{Mn}-\mathrm{O}(5)\{$ water $\}$ of $156.2(1)-162.2(1)^{\circ}$ is substantially deviated from linearity. Such bending is probably a result of the presence of the chelating

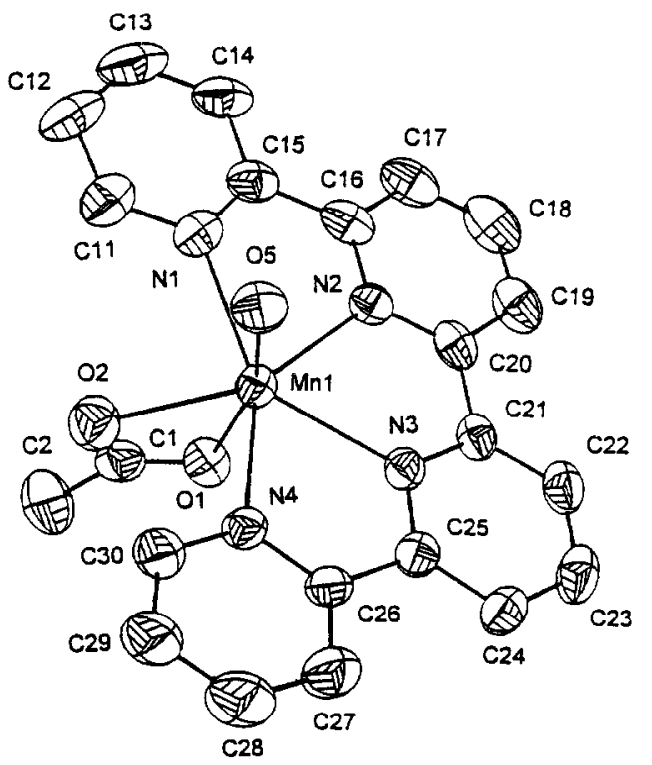

Fig. 1. ORTEP view of $\left[\mathrm{Mn}(\mathrm{QP})\left(\mathrm{H}_{2} \mathrm{O}\right)\left(\mathrm{CH}_{3} \mathrm{CO}_{2}\right)\right]^{+}$. 


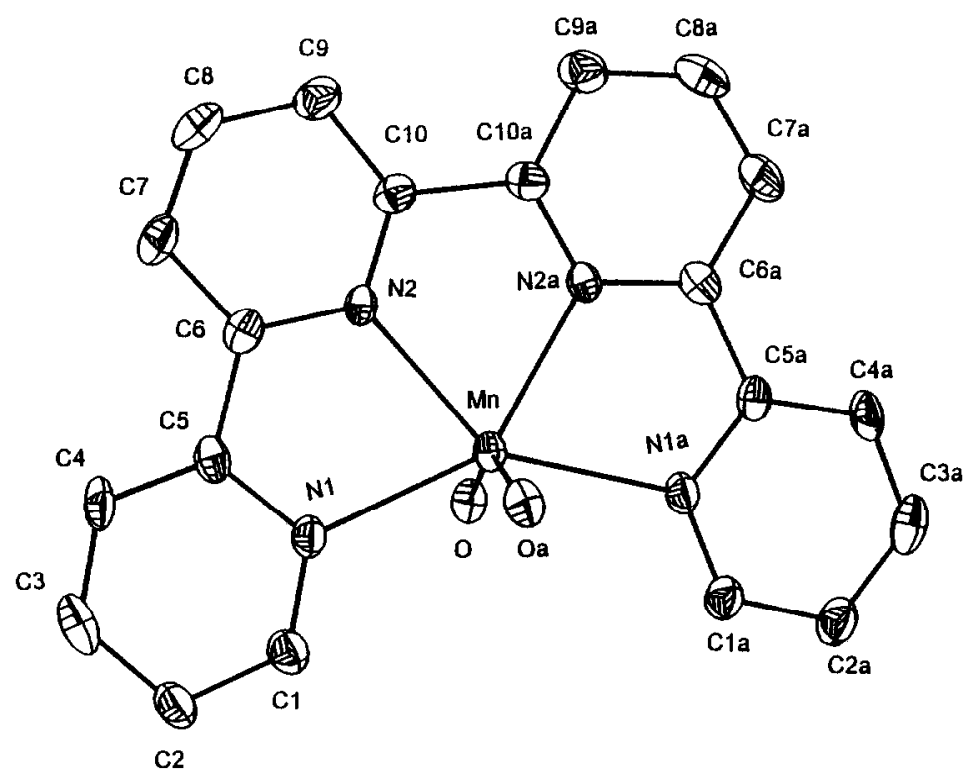

Fig. 2. ORTEP view of $\left[\mathrm{Mn}(\mathrm{QP})\left(\mathrm{H}_{2} \mathrm{O}\right)_{2}\right]^{2+}$.

acetate ligand and the large void angle defined by $\mathrm{N}(1)-\mathrm{Mn}-\mathrm{N}(4)$, similar to the situation in 2.

A comparison between the reported structure with that of $\left[\mathrm{Ni}(\mathrm{QP})\left(\mathrm{CH}_{3} \mathrm{CN}\right)_{2}\right]\left[\mathrm{PF}_{6}\right]_{2},{ }^{3}[\mathrm{Pt}(\mathrm{QP})]$ $\left(\mathrm{ClO}_{4}\right)_{2}{ }^{4 b}$ and $\left.\left[\mathrm{Co}(\mathrm{QP})\left(\mathrm{H}_{2} \mathrm{O}\right)\left(\mathrm{SO}_{3}\right)\right]\left(\mathrm{NO}_{3}\right)\right] \cdot \mathrm{H}_{2} \mathrm{O}^{5}$ reveals much smaller $\mathrm{N}(1)-\mathrm{M}-\mathrm{N}(4)$ void angles for the nickel(II), platinum(II) and cobalt(II) complexes. This is in accord with previous works which indicated that sevencoordinated metal complexes of $\mathrm{QP}$ have much larger $\mathrm{N}(1)-\mathrm{M}-\mathrm{N}(4)$ void angles.

The structures of six-coordinated 2 can best be described as a skew-trapezoidal-bipyramid (see Fig. 2). The short edge is comprised of two central pyridyl rings, while the long edge can be imagined as two terminal pyridyl rings and the void between them. Upon coordination the water molecules in the axial positions skew towards the long axis of the trapezoid, i.e. the open end of QP, with $\angle \mathrm{O}(1)-\mathrm{Mn}-\mathrm{O}(1 \mathrm{~A})$ at $150.0(2)^{\circ}$. Furthermore, the absence of a fifth equatorial coordinated atom in complex 2 allowed closer approach of the axial oxygen atoms and the equatorial nitrogen atoms.

In these structures two mirror planes were retained and the quaterpyridines are essentially coplanar.

The two central $\mathrm{Mn}-\mathrm{N}$ bonds in both $\mathbf{1}$ and 2 are slightly shorter than the two outer $\mathrm{Mn}-\mathrm{N}$ bonds. This may be due to the constrained effect of the quaterpyridine ligand. Nevertheless, these $\mathrm{Mn}-\mathrm{N}$ distances are normal and comparable to those values of 2.276(4)-2.328(4) $\&$ found in [Mn $($ dapb $\left.)\left(\mathrm{H}_{2} \mathrm{O}\right) \mathrm{Cl}\right] \mathrm{Cl} \quad[$ dapb $=2,6$-diacetylpyridinebis(benzoylhydrazone)]. ${ }^{6}$ The $\mathrm{Mn}-\mathrm{O}(5)$ \{water\} distance of $\mathbf{1}$ is somewhat shorter than the average $\mathrm{Mn}-\mathrm{O}(1),(2)$ acetate\} distance, probably due to the limited $\angle \mathrm{O}(1)-\mathrm{C}(1)-\mathrm{O}(2)$ bite angle of acetate.

As the extent of $\mathrm{QP}$ distortions in both 1 and 2 are almost the same [ $\angle \mathrm{N}(1)-\mathrm{C}(15)$ $\mathrm{C}(16)=114.9(3)-115.6(3), \angle \mathrm{N}(2)-\mathrm{C}(20)-\mathrm{C}(21)=$ 115.2(4)-115.4(4); $\quad \angle \mathrm{N}(1)-\mathrm{C}(5)-\mathrm{C}(6)=116.4(6)$, $\angle \mathrm{N}(2)-\mathrm{C}(10)-\mathrm{C}(10 \mathrm{~A})=114.3(6)]$ the almost equal magnitude of void angles in coordinated QP for both seven- and six-coordinate manganese(II) indicates that isolation of the seven-coordinated manganese(II) quaterpyridine complex is possible as long as suitable chelating molecules are present. Furthermore, the larger void angle of complex 2 comparcd with $[\mathrm{Pt}(\mathrm{QP})]\left(\mathrm{ClO}_{4}\right)_{2}{ }^{4 b}$ suggests strong interaction of $\mathrm{QP}$ with third row transition elements.

Interestingly enough, the quinquepyridine manganese(II) complex was not available from direct synthesis, which was found to be retarded by water. ${ }^{8}$ This result was consistent with the fact that manganese(II) generally has a stronger preference for oxygen than nitrogen. The isolation of quaterpyridine manganese(II) complexes again demonstrates the unique chelating strength of four rigidly bridged equatorial pyridyl units.

\section{Electrochemistry}

The generation of manganese(III) from complex 2 using the cyclic voltammetric method was unsuccessful as complex 2 was unstable towards decomposition in aqueous solution. A voltammograph was recorded in degassed acetonitrile 
Table 3. Epoxidation catalysed by $\left[\mathrm{Mn}(\mathrm{QP})\left(\mathrm{H}_{2} \mathrm{O}\right)_{2}\right]\left(\mathrm{ClO}_{4}\right)_{2}(2)$

\begin{tabular}{ccccc} 
& Cis-stilbene $^{a}$ & Trans-stilbene $^{a}$ & Styrene $^{b}$ & Norbornene $^{b}$ \\
\hline Turnover & $\mathbf{1}^{c}$ & $4^{c}$ & $16^{d}$ & $3^{e}$ \\
& $0.3^{f}$ & & & \\
\hline
\end{tabular}

${ }^{a}$ Reaction time $6 \mathrm{~h}$.

${ }^{b}$ Reaction time $3 \mathrm{~h}$.

${ }^{c}$ Trans-stilbene oxide.

${ }^{d}$ Styrene oxide.

e Exo-2,3-epoxynorbornane.

${ }^{f}$ Cis-stilbene oxide.

solution [0.1 M $\left.\left(\mathrm{CH}_{3}\left(\mathrm{CH}_{2}\right)_{3}\right)_{4} \mathrm{NPF}_{6}\right]$, which can afford an oxidative scan up to $+2.5 \mathrm{~V}$. However, no oxidative wave was observed within this condition. Reduction of 2 was observed at $c a-1.7 \mathrm{~V}$ (vs $\mathrm{Fc}^{+} / \mathrm{Fc}$ ), which was believed to be ligand-centre reduction. ${ }^{9}$

\section{Alkene epoxidation by $\mathrm{PhIO}$}

Complex 2 was found to catalyse alkene epoxidation by PhIO. A lightly coloured suspension of the reaction mixture turned into a dark green solution within minutes. The reaction was found to be non-stereospecific as cis-stilbene gives both transand cis-stilbene oxide with more than $70 \%$ transisomer (see Table 3). Oxo-transfer was more effective with less sterically hindered alkenes as the turnover number for styrene was four times greater than that of trans-stilbene and about 20 -fold to that of cis-stilbene. $\Lambda$ small amount of benzaldehyde was detected for styrene oxidation.

Acknowledgements--We acknowledge support from The University of Hong Kong and the National Science Council of Taiwan. CMC acknowledges a visiting pro- fessorship, administered by the National Taiwan University.

\section{REFERENCES}

1. E. C. Constable, Adv. Inorg. Chem. Radiochem. 1986, 30, 69.

2. E. C. Constable, Adv. Inorg. Chem. Radiochem. 1989, 34, 1.

3. E. C. Constable, S. M. Elder, J. Healy and D. A. Tocher, J. Chem. Soc., Dalton Trans. 1990, 1669.

4. (a) C. M. Che, Y. P. Wang, K. S. Yeung, K. Y. Wong and S. M. Peng, J. Chem. Soc., Dalton Trans. 1992, 2675 ; (b) C. W. Chan, C. M. Che, M. C. Cheng and Y. Wang, Inorg. Chem. 1992, 31, 4874.

5. E. N. Maslen, C. L. Raston and A. H. White, J. Chem. Soc., Dalton Trans. 1975, 323.

6. C. M. Che, K. Y. Wong and F. C. Anson, J. Electroanal. Chem. 1987, 226, 211.

7. C. Lorenzini, C. Pelizzi, G. Pelizzi and G. Predieri, $J$. Chem. Soc., Dalton Trans. 1983, 721.

8. E. C. Constable, J. Lewis and M. Schröder, Poly hedron 1982, 1, 311.

9. (a) C. W. G. Ansell, J. Lewis, J. N. Ramsden and M. Schröder, Polyhedron 1983, 2, 489; (b) E. C. Constable, S. M. Elder and D. A. Tocher, Polyhedron 1992, 11, 1337. 